\title{
ANALISIS PEMAHAMAN KONSEP MAKROSKOPIK- SUBMIKROSKOPIK-SIMBOLIK MENGGUNAKAN PENDEKATAN SUBMIKROSKOPIK PADA MATERI LARUTAN ASAM BASA
}

\section{Analysis Of Understanding The Concept Of Macroscopic-Submicroscopic- Symbolic using Submicroscopic Approach in Acid Base Solution Materials}

\section{Laila Safitri*, Atiek Winarti, Bambang Suharto}

Program Studi Pendidikan Kimia FKIP Universitas Lambung Mangkurat, Jl. Brigjend. H. Hasan Basry Banjarmasin 70123 Kalimantan Selatan Indonesia *email: lailasafitry05@gmail.com

\begin{abstract}
Abstrak. Telah dilakukan analisis pemahaman konsep makroskopiksubmikroskopik-simbolik pada materi larutan asam basa pada siswa SMAN 8 Banjarmasin menggunakan pendekatan submikroskopik. Penelitian ini mengidentifikasi; (1) pemahaman konsep siswa pada materi larutan asam basa, (2) meningkatkan pemahaman konsep siswa pada materi larutan asam basa melalui pendekatan submikroskopik, (3) aktivitas guru mengelola pembelajaran, (4) aktivitas belajar siswa. Kegiatan ini berupa penelitian tindakan kelas (PTK) dengan 2 siklus terdiri dari perencanan, pelaksanan tindakan, observasi dan evaluasi, serta refleksi. Subjek penelitian adalah siswa kelas XI MIPA 4 SMAN 8 Banjarmasin berjumlah 29 orang. Data dianalisis secara kualitatif dan kuantitatif. Hasil penelitian menunjukkan bahwa; (1) pemahaman konsep awal siswa level makroskopik 45,5\% (rendah), submikroskopik $8,5 \%$ (sangat rendah), dan simbolik $48 \%$ (rendah), (2) pembelajaran menggunakan pendekatan submikroskopik meningkatkan pemahaman konsep siswa pada level makroskopik sebesar 86,5\% (sangat tinggi), submikroskopik sebesar 64,75\% (cukup), dan simbolik sebesar 80,25\% (sangat tinggi), (3) peningkatan skor aktivitas guru dari 42 (baik) siklus I menjadi 51 (sangat baik) pada siklus II, (4) peningkatan skor aktivitas siswa dari 37,66 (aktif) siklus I menjadi 46,83 (sangat aktif) pada siklus II.
\end{abstract}

Kata kunci: pemahaman konsep, pendekatan submikroskopik, level makroskopik, level submikroskopik, level simbolik

\begin{abstract}
Research has been carried out on the Analysis of Concept Understanding Macroscopic-Submicroscopic-Symbolic in Basic Acid Solution Materials in Students of SMAN 8 Banjarmasin Using Submicroscopic Approach. This study identifies; (1) understanding of student concept in acidbase solution materials, (2) increasing understanding of student concepts in acid-base solution materials through a submicroscopic approach, (3) teacher activities managing learning, (4) student learning activities. This activity is a classroom action research (CAR) with 2 cycles consisting of planning, action, observation and evaluation, and reflection. The research subjects were student class XI MIPA 4 SMAN 8 Banjarmasin totaling 29 people. Data are analyzed qualitatively and quantitatively. The results of the study show that; (1) understanding of the concept of early student macroscopic level of $45.5 \%$ (low), submicroscopic $8.5 \%$ (very low), and symbolic 48\% (low), 2) learning using the submicroscopic approach increasing the understanding of the concept of student at a macroscopic level of $86.5 \%$ (very high), submicroscopic at $64.75 \%$ (sufficient), and symbolic at $80.25 \%$ (very high), (3) the increase in teacher activity scores from 42 (good) cycle I to 51 (very good) in cycle II, (4) increase in activity scores student from 37.66 (active) cycle I to 46.83 (very active) in cycle II.
\end{abstract}

Copyright @ JCAE-Jurnal Tugas Akhir Mahasiswa, e-ISSN 2613-9782

Program Studi Pendidikan Kimia FKIP Universitas Lambung Mangkurat 
Keywords: Understanding of the Concept, Submicroscopic Approach, Macroscopic Level, Submicroscopic Level, Symbolic Level

\section{PENDAHULUAN}

Ilmu kimia adalah salah satu cabang dari ilmu pengetahuan alam (IPA) berkaitan terhadap sifat-sifat zat, struktur zat, perubahan zat, hukum dan prinsip yang menggambarkan perubahan zat, serta konsep dan teori yang menjelaskan terjadinya perubahan zat (Effendy, 2016). Dalam permendikbud RI Nomor 59 tahun 2014 tentang kurikulum 2013 SMA/MA dinyatakan bahwa mata pelajaran kimia SMA/MA memiliki tujuan untuk: (1) memahami konsep-konsep kimia dan saling keterkaitannya. (2) menerapkan konsep-konsep kimia untuk menyelesaikan masalah dalam kehidupan sehari-hari dan teknologi. Adanya kurikulum 2013 dalam mata pelajaran kimia diharapkan siswa mampu memahami dan menerapkan konsep-konsep kimia secara utuh dan benar.

Johnstone menginterpretasikan pengetahuan dan pemahaman kimia dalam tiga level, yaitu makroskopik, submikroskopik, dan simbolik (Talanquer, 2010). Level Makroskopik merupakan bagian dari ilmu kimia yang dapat terlihat atau tidak dari pengalamann sehari-hari. Konsep makroskopik digeneralisasikan dari pengamatan langsung terhadap gejala alam atau hasil eksperimen (Sihaloho, 2012). Level submikroskopik merupakan bagian dari tingkatan partikulat yang menjelaskan pergerakan elektron, molekul, partikel, atau atom. Level simbolik merupakan bagian dari representasi bergambar, aljabar, dan bentuk komputasi (Chittleborough, 2004).

Umumnya pembelajaran dalam kimia hanya menekankan pada level makroskopik dan simbolik, sedangkan level submikroskopik belum. Salah satu contoh pada materi asam kuat dan basa kuat, siswa tidak dapat membedakan konsepnya secara submikroskopik, meskipun secara simbolik siswa dapat membedakannya dengan menggunakan anak panah (Sunyono, 2015). Hal tersebut dapat menimbulkan pemahaman yang salah dan mengakibatkan siswa membuat interpretasi sendiri tentang gambaran submikroskopik. Pemahaman pada level submikroskopik yang kurang ditekankan ini dapat menyebabkan siswa mengalami kesulitan dalam mengembangkan pemahaman konseptualnya (Indrayani, 2013).

Hasil wawancara terhadap guru kimia yang mengajar kelas XI MIPA SMA Negeri 8 Banjarmasin diketahui materi larutan asam basa tergolong materi yang sulit dipahami bagi siswa. Siswa masih kesulitan pada konsep asam basa Bronsted-Lowry dengan asam basa konjugasinya, mereka kesulitan dalam menentukan donor proton dan yang merupakan akseptor proton dari suatu reaksi. Siswa juga kesulitan pada konsep asam basa berdasarkan Lewis. Berdasarkan pengalaman tahun sebelumnya nilai siswa terhadap pemahaman konsep materi asam basa pada level makroskopik dengan nilai 68 dan level simbolik dengan nilai 57, pemahaman konsep ini masih tergolong rendah. Sedangkan nilai pemahaman konsep siswa pada level submikroskopik masih belum dilakukan penilaian secara khusus. Pemahaman konsep ini sangat penting diperbaiki guna untuk mengatasi terjadinya kesalahan pemahaman konsep siswa pada materi larutan asam basa pada level makroskopik, level simbolik dan terutama pada level submikroskopik.

Pemberian pembelajaran ulang dengan pendekatan submikroskopik mampu meningkatkan pemahaman konseptual siswa (Indrayani, 2013). Pendekatan submikroskopik adalah pendekatan pembelajaran yang dilakukan dengan menafsirkan, memahami, dan menjelaskan fakta, prinsip, serta hukum kimia yang bersifat partikulat (Yani, Yusrizal, \& Khaldun, 2015). Pendekatan submikroskopik ini mengacu pada hasil penelitian Devetak, Vogrinc, \& Glazar (2007) yang menyatakan 
representasi submikroskopik dapat membantu siswa dalam mengembangkan pemahaman konsep. Smith \& Metz (1996) menyatakan bahwa pengajaran kimia dengan menggunakan bantuan visual secara submikroskopik dapat meningkatkan pemahaman siswa.

\section{METODE PENELITIAN}

Penelitian ini merupakan penelitian tindakan kelas (PTK). Adapun tiap siklus tersusun atas dua kali pembelajaran dan satu kali tes pemahaman konsep di akhir siklus. Subjek penelitian seluruh siswa kelas XI MIPA 4 SMAN 8 Banjarmasin berjumlah 29 orang dari 11 orang laki-laki dan 18 orang perempuan.

Teknik analisis data berupa analisis kualitatif dan kuantitatif. Instrumen ini berupa tes dan nontes. Instrumen tes berupa tes pemahaman konsep berbentuk soal pilihan ganda dengan pilihan alasan masing-masing sebanyak 10 yang mengacu pada indikator materi larutan asam basa dengan level makroskopik, submikroskopik, dan simbolik. Sedangkan instrumen non tes yaitu lembar observasi aktivitas guru, siswa, dan afektif siswa.

\section{HASIL PENELITIAN DAN PEMBAHASAN} akhir siklus.

Hasil pemahaman konsep siswa yang didapatkan dari observasi awal dan tes

Pemahaman Konsep Makroskopik, Submikroskopik, dan Simbolik Siswa Sebelum Belajar

Pemahaman konsep pada level makroskopik, submikroskopik, dan simbolik siswa di kelas XI MIPA SMAN 8 Banjarmasin pada observasi awal dapat dilihat pada Gambar 1.

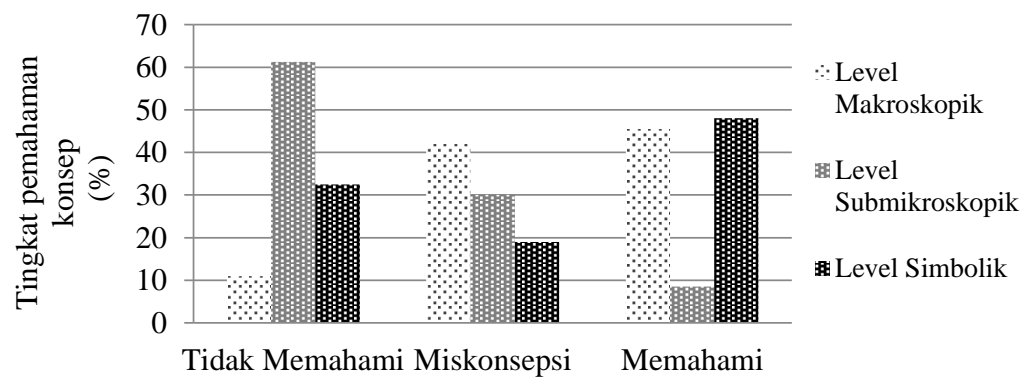

Gambar 1. Pemahaman Konsep Makroskopik, Submikroskopik, dan simbolik siswa sebelum belajar

Gambar 1 menunjukkan kriteria memahami pada level makroskopik dan simbolik memiliki perbedaan yang tidak terlalu jauh, yakni 2,5\%, sedangkan level submikroskopik memiliki perbedaan yang sangat jauh dengan level makroskopik dan simbolik. Hal ini menunjukkan bahwa pada tes observasi awal pemahaman konsep siswa pada level submikroskopik masih dalam kategori sangat rendah dan pemahaman konsep siswa pada level makroskopik dan simbolik kategori rendah.

Berdasarkan hasil jawaban tes observasi awal, peneliti memberikan tindakan berupa pembelajaran dengan menggunakan pendekatan submikroskopik agar pemahaman konsep siswa pada level makroskopik, submikroskopik, dan simbolik dapat meningkat dari sebelumnya, terutama level submikroskopik. 
Pemahaman Konsep Makroskopik, Submikroskopik, dan Simbolik Siswa Sesudah Pembelajaran Siklus I dan II

Berdasarkan hasil pemahaman konsep siswa menjawab benar dalam memahami konsep larutan asam basa menggunakan pendekatan submikroskopik yang dapat dilihat Tabel 1.

Tabel 1. Persentase Menjawab Benar dalam Memahami Konsep Larutan Asam Basa Menggunakan Pendekatan Submikroskopik

\begin{tabular}{|c|c|c|c|c|c|c|c|}
\hline \multirow{2}{*}{ Siklus } & \multirow{2}{*}{ Indikator yang diukur } & \multicolumn{3}{|c|}{ No. Soal } & \multicolumn{3}{|c|}{$\%$} \\
\hline & & I & II & III & I & II & III \\
\hline \multirow{5}{*}{1} & $\begin{array}{l}\text { Menjelaskan konsep asam } \\
\text { dan basa Arrhenius }\end{array}$ & 1 & 2 & 3 & 69 & 55 & 69 \\
\hline & $\begin{array}{l}\text { Menjelaskan konsep asam } \\
\text { dan basa Bronsted-Lowry }\end{array}$ & 4 & - & - & 62 & - & - \\
\hline & $\begin{array}{l}\text { Menentukan persamaan } \\
\text { reaksi asam basa Bronsted- } \\
\text { Lowry dengan pasangan } \\
\text { asam basa konjugasinya }\end{array}$ & 5 & 6 & 7 & 62 & 45 & 58 \\
\hline & $\begin{array}{l}\text { Menjelaskan asam dan basa } \\
\text { menurut Lewis }\end{array}$ & 8 & - & - & 65 & - & - \\
\hline & $\begin{array}{l}\text { Menentukan persamaan } \\
\text { reaksi asam bsaa Lewis }\end{array}$ & - & 9 & 10 & - & 51 & 62 \\
\hline \multicolumn{5}{|c|}{ Rata-rata } & 64,5 & 50,33 & 63 \\
\hline 2 & $\begin{array}{l}\text { Menentukan kesetimbangan } \\
\text { pengionan dalam larutan } \\
\text { asam basa }\end{array}$ & 1,2 & $\begin{array}{l}3,4, \\
5,6,\end{array}$ & $\begin{array}{l}7,8 \\
9,10\end{array}$ & $\begin{array}{l}90 \\
83\end{array}$ & $\begin{array}{c}76 \\
62 \\
62,59 \\
\end{array}$ & $\begin{array}{c}86, \\
83, \\
76,76 \\
\end{array}$ \\
\hline \multicolumn{5}{|c|}{ Rata-rata } & 86,5 & 64,75 & 80,25 \\
\hline
\end{tabular}

Keterangan:

$\begin{array}{ll}\text { I } & =\text { Makroskopik } \\ \text { II } & =\text { Submikroskopik } \\ \text { III } & =\text { Simbolik }\end{array}$

Berdasarkan hasil penelitian Tabel 1, pada siklus 1 persentase siswa dalam menjawab benar soal pemahaman konsep pada level makroskopik dalam menjelaskan konsep asam dan basa Arrhenius yaitu paling tinggi sebesar 69\%. Berdasarkan teori Arrhenius, asam merupakan suatu zat yang apabila dilarutkan dalam air akan menghasilkan ion $\mathrm{H}+$ dan basa merupakan suatu zat yang apabila dilarutkan dalam air menghasilkan ion OH-. Persentase siswa paling rendah yang menjawab benar soal pemahaman konsep adalah menjelaskan konsep asam dan basa Bronsted-Lowry serta menentukan persamaan reaksi asam basa Bronsted-Lowry dengan pasangan asam basa konjugasinya yaitu $62 \%$. Berdasarkan Tabel 1, rata-rata persentase pemahaman konsep siswa pada level makroskopik sebesar 64,5\% termasuk kategori cukup.

Tabel 1, persentase siswa pada siklus 1 dalam menjawab benar soal pemahaman konsep pada level submikroskopik dalam menjelaskan konsep asam dan basa Arrhenius yaitu paling tinggi sebesar 55\%. Dimana siswa dapat menjelaskan asam dalam gambaran submikroskopik bahwa asam kuat yang dilarutkan dalam air akan terionisasi sempurna. Jika dibandingkan antara tes observasi awal dengan tes akhir siklus 1 pemahaman konsep siswa mengalami peningkatan yang tinggi. Hal ini serupa dengan penelitian Winarti, Almubarak, \& Bakti (2018) bahwa pemahaman konsep mikroskopik sangat penting untuk mendukung pemahaman keseluruhan konsep. Persentase terendah siswa pada level submikroskopik adalah $45 \%$ dalam 
menentukan persamaan reaksi asam basa Bronsted-Lowry dengan pasangan asam basa konjugasinya. Berdasarkan Tabel 1, rata-rata persentase siklus 1 pemahaman konsep siswa pada level submikroskopik adalah 50,33\% dan termasuk kategori rendah.

Berdasarkan Tabel 1, persentase tertinggi siswa siklus 1 pada level simbolik dalam menjawab benar soal pemahaman konsep yaitu 69\% dalam menjelaskan konsep asam dan basa Arrhenius dan persentase terendah yaitu $58 \%$ dalam menentukan persamaan reaksi asam basa Bronsted-Lowry dengan pasangan konjugasinya. Berdasarkan Tabel 1, rata-rata persentase siklus 1 pemahaman konsep siswa pada level simbolik adalah $63 \%$ dan termasuk kategori cukup.

Peningkatan pemahaman konsep siswa pada level makroskopik, submikroskopik, dan simbolik yang dilakukan pada siklus 2 mengalami peningkatan untuk masing-masing level. Hal ini dapat dilihat pada Tabel 1 dengan rata-rata persentase siswa dalam menjawab benar soal pemahaman konsep yaitu level makroskopik 86,5\% (sangat tinggi), submikroskopik 64,75\% (cukup), dan simbolik $80,25 \%$ (sangat tinggi).

\section{Analisis Aktivitas Guru} pada Gambar 2 .

Berdasarkan hasil yang diperoleh dari observer aktivitas guru dapat dilihat

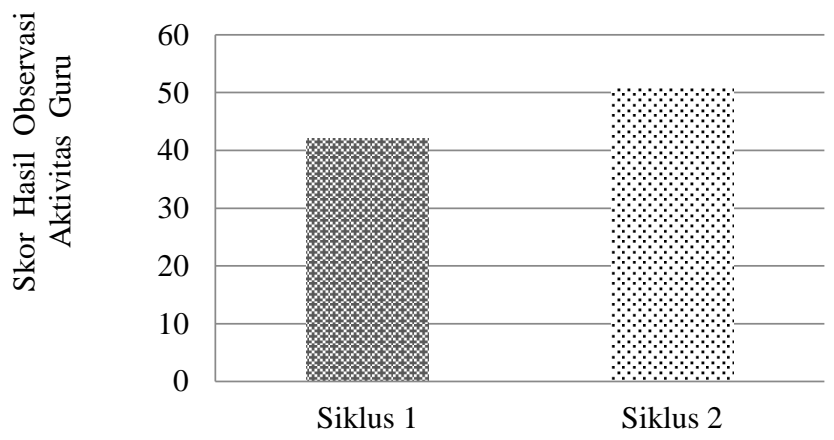

\section{Gambar 2. Hasil Observasi Aktivitas Guru}

Gambar 2 di atas hasil yang diperoleh bahwa skor aktivitas guru terhadap siklus 1 yaitu 42 dengan kategori baik, mengalami peningkatan pada siklus 2 menjadi 51 termasuk kategori sangat baik. Hal ini guru telah berhasil memperbaiki kekurangan yang terjadi pada siklus 1 . Pada pertemuan pertama tahap menjelaskan pendekatan submikroskopik salah satunya dengan memberikan contoh-contoh gambaran submikroskopik telah memberikan kesan yang baik sehingga siswa menjadi tertarik untuk mengikuti pembelajaran. Pertemuan berikutnya guru telah berusaha secara maksimal untuk memberikan materi pembelajaran dengan menggunakan pendekatan submikroskopik, model dan metode pembelajaran yang telah disusun. Secara keseluruhan guru telah mampu menyampaikan materi larutan asam basa dengan sangat baik dan maksimal.

\section{Analisis Aktivitas Siswa}

Hasil yang diperoleh dari observer aktivitas siswa dapat dilihat pada Gambar 3. 


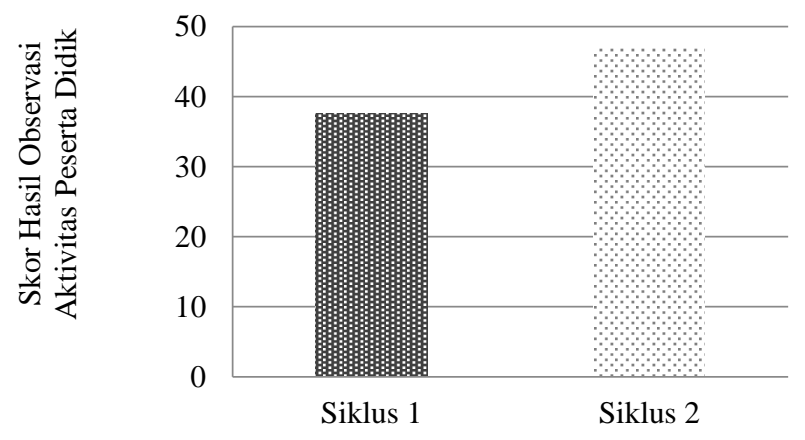

\section{Gambar 3. Hasil Observasi Aktivitas Siswa}

Berdasarkan hasil obervasi yang diperoleh terlihat pada Gambar 2 bahwa aktivatas siswa mengalami peningkatan dari siklus 1 sebesar 37,66 dengan kategori aktif menjadi 46,83 pada siklus 2 dengan kategori sangat aktif. Peningkatan ini dipengaruhi oleh aktivitas guru yang meningkat di setiap siklusnya. Pada pertemuan awal, siswa masih kebingungan mengerjakan latihan di LKPD dengan penggambaran submikroskopik, namun guru membimbing siswa sampai mengerti dan dapat mengerjakan latihan di LKPD dengan baik. Guru juga selalu membimbing siswa ketika mengalami kesulitan dalam menerima materi yang dibahas pada pertemuan tersebut, sehingga interaksi antara guru dengan peserta didik berjalan dengan lancar. Peningkatan ini juga menunjukkan bahwa perbaikan kekurangan pada siklus 1 dapat diterapkan dengan baik pada siklus 2 .

\section{Keefektifan Pendekatan Submikroskopik}

Berdasarkan data hasil penelitian pada Tabel 1, Rata-rata persentase pemahaman konsep siswa pada level makroskopik, submikroskopik, dan simbolik siswa pada akhir tes siklus dilihat pada Gambar 4.

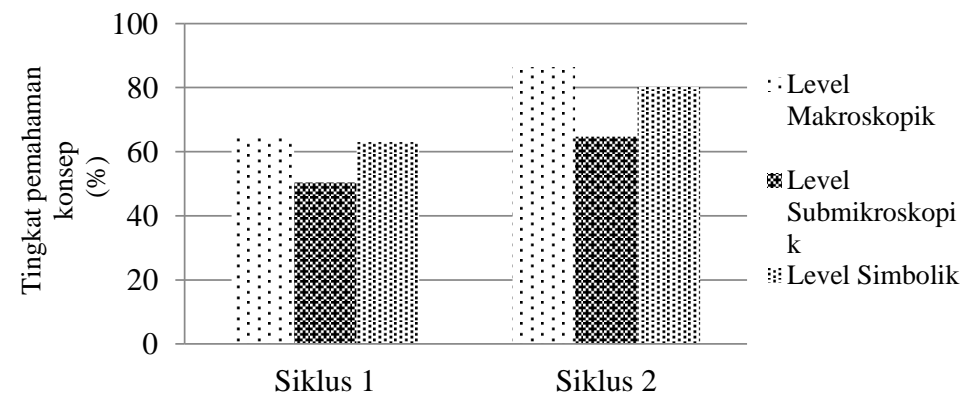

\section{Gambar 4. Rata-rata Persentase Hasil Tes Pemahaman Konsep}

Berdasarkan Gambar 4, proses pembelajaran dengan menggunakan pendekatan submikroskopik memberikan efek positif terhadap pemahaman konsep siswa pada level makroskopik, submikroskopik, dan simbolik. Hal ini dibuktikan dengan meningkatnya pemahaman konsep setiap siklusnya. Peningkatan ini berdasarkan hasil tes akhir siklus yang dilakukan setiap pembelajaran akhir siklus berakhir. Oleh karena itu hasil ini serupa terhadap penelitian yang dilakukan oleh: Smith \& Metz (1996) pengajaran kimia dengan menggunakan bantuan visual secara submikroskopik dapat meningkatkan pemahaman siswa; Devetak, Vogrinc, \& Glazar 
(2007) penggunaan level submikroskopik dapat membantu siswa dalam mengembangkan pemahaman konsep dan pemecahan masalah; Indrayani (2013) pemberian pembelajaran ulang dengan pendekatan mikroskopik mampu meningkatkan pemahaman konseptual terhadap tingkat pemahaman makroskopik, mikroskopik, dan simbolik siswa; Yanto, Enawaty, \& Erlina (2013) pengembangan lembar kerja siswa (LKS) menggunakan pendekatan mikroskopik efektif dalam pembelajaran siswa; Yani, Yusrizal, \& Khaldun (2015) pembelajaran dengan pendekatan mikroskopik melalui lembar kerja peserta didik (LKPD) efektif meningkatkan kemampuan berpikir kritis serta pemahaman konsep siswa. Dengan demikian dikatakan bahwa penerapan pendekatan submikroskopik efektif dalam meningkatkan pemahaman konsep siswa pada level makroskopik, submikroskopik, dan simbolik.

\section{SIMPULAN}

Pemahaman konsep siswa kelas XI MIPA SMAN 8 Banjarmasin pada materi larutan asam basa sebelum diterapkan pendekatan submikroskopik pada level makroskopik dan simbolik termasuk pada kategori rendah dan level submikroskopik termasuk pada kategori sangat rendah. Penerapan pendekatan submikroskopik pada pembelajaran larutan asam basa kelas XI MIPA SMAN 8 Banjarmasin mengalami peningkatan setiap siklus 1 hingga siklus 2 , level makroskopik dan simbolik termasuk pada kategori dari cukup menjadi sangat tinggi dan level submikroskopik termasuk pada kategori dari rendah menjadi cukup. Aktivitas guru dalam menerapakan pendekatan submikroskopik pada pembelajaran larutan asam basa meningkat setiap pertemuan siklus 1 hingga siklus 2 dengan pencapaian kategori dari baik menjadi sangat baik. Aktivitas siswa dalam mengikuti pembelajaran larutan asam basa menggunakan pendekatan submikroskopik meningkat setiap pertemuan siklus 1 hingga siklus 2 dengan pencapaian kategori dari aktif menjadi sangat aktif.

\section{DAFTAR RUJUKAN}

Chittleborough, G. D. (2004). The Role of Teaching Models and Chemical Representations in Developing Students' Mental Models of Chemical Phenomena. Australia: Curtin University of Technology.

Devetak, I., Vogrinc, J., \& Glazar, S. (2007). Assessing 16-Year-Old Students Understanding of Aqueous Solution at Submicroscopic Level. Research in Science Education , 157-179.

Effendy. (2016). Ilmu Kimia Untuk Siswa SMA dan MA Kelas X. Malang: Indonesian Academic Publishing.

Indrayani, P. (2013). Analisis Pemahaman Makroskopik, Mikroskopik, dan Simbolik Titrasi Asam-Basa Siswa Kelas XI IPA SMA serta Upaya Perbaikannya Dengan Pendekatan Mikroskopik. Jurnal Pendidikan Sains , 1 (2) : 109-120.

Sihaloho, M. (2012). Analisis Kesalahan Siswa Dalam Memahami Konsep Larutan Buffer pada Tingkat Makroskopik dan Mikroskopik. Yogyakarta: UNG.

Smith, K., \& Metz, P. (1996). Evaluating Student Understanding of Solution Chemistry Through Microscopic Representations. Journal of Chemical Education, 233-235.

Sunyono. (2015). Model Pembelajaran Multipel Representasi. Yogyakarta: Media Akademi.

Talanquer, V. (2010). Macro, Submicro, and Symbolic: The Many Faces Of The Chemistry "Triplet". International Journal of Science Education , 179-195.

Winarti, A., Almubarak, \& Bakti, I. (2018). Identifying Microscopic Understanding of Chemistry Education Students and Its Relationship with Multiple 


\section{ANALISIS PEMAHAMAN KONSEP MAKROSKOPIK}

Intelligences and Learning Style. Advances in Social Science, Education and Humanities Research , 256-259.

Yani, H., Yusrizal, \& Khaldun, I. (2015). Efektivitas Pendekatakan Mikroskopik Dalam Lembar Kerja Siswa (LKPD) Terhadap Pemahaman Konsep dan Kemampua Berpikir Kritis pada Materi Larutan Penyangga. Jurnal Pendidikan Sains Indonesia , 38-46.

Yanto, R., Enawaty, E., \& Erlina. (2013). Pengembangan Lembar Kerja Siswa (LKS) dengan Pendekatan Makroskopik-Mikroskopik-Simbolik Pada Materi Ikatan Kimia. Jurnal Pendidikan dan Pembelajaran , 1-9 